\title{
Analyzing the Thematic-Integrative Content, the Scientific Approach, and the Authentic Assessment in the Theme 1 Textbook for Grade II Students of Elementary Schools
}

\author{
Putri Zudhah Ferryka \\ Department of Elementary School Teacher Education,Universitas Widya Dharma Klaten. Jalan Ki \\ Hajar Dewantara, Karanganom, Klaten, 57400, Indonesia \\ Email: zudhah_putri@yahoo.com, Telp: +62272322363 \\ Received: 31 May 2017; Revised: 22 June 2017; Accepted: 12 July 2017
}

\begin{abstract}
This study aimed at describing the integrative-thematic content, the scientific approach, and the authentic assessment in the 2013 Curriculum Theme 1 Textbook Peaceful Life for the Grade II Students of Elementary School. This study was a content analysis research using a qualitative approach. The subject in this study was 2013 Curriculum Theme 1 Textbook Peaceful Life for the Grade II Students of Elementary School. Then, the objects of this study were integrative-thematic content, scientific approach, and authentic assessment. The data analysis that the researcher employed consisted of data gathering, sample selecting, data recording, data reducing, conclusion drawing, and narrating. The results of the study show that: (1) most of the integrative-thematic contents in the 2013 Curriculum Theme 1 Textbook Peaceful Life for the Grade II Students of Elementary School have been in accordance with the indicators but the author still make some errors within the contents; (2) the scientific approach that has been embedded into the textbook includes various activities that direct the students to interact with their environment in establishing their own knowledge; and (3) the authentic assessment has been in accordance with the indicators.
\end{abstract}

Keyword: authentic assessment, scientific approach, textbook, thematic-integrative

How to Cite: Ferryka, P. (2017). Analyzing the thematic-integrative content, the scientific approach, and the authentic assessment in the theme 1 textbook for grade II students of elementary schools. Jurnal Prima Edukasia, 5(2), 172-185. doi:http://dx.doi.org/10.21831/jpe.v5i2.14285

Permalink/DOI: http://dx.doi.org/10.21831/jpe.v5i2.14285

\section{Introduction}

The national education system is expected to equip the graduates for competing with the other nations throughout the world. In responding to this expectation, the Ministry of Education and Culture has been pursuing a series of updates on the education system in order that Indonesia becomes an advanced nation with characters. This statement is in accordance with the objective and the function of the national education as having been formulated in the Law of National Education System (UUSPN, Undang-Undang Sistem Pendidikan Nasional) Number 20 Year 2003 Article 3. In this law, it is mentioned that education serves to develop the skills and the shape the characters and the civilization of a dignified nation in order to enlighten the life of the nation (Presiden Republik Indonesia, 2003).
Multiples efforts have been pursued in order to meet this expected and one of the efforts in revising the curriculum. This curriculum revision is expected to improve the quality of the human resources so that the educational objectives and targets might be achieved in maximum. In other words, 2013 Curriculum that has been implemented up to date serves as a revision for the Educational Unit Level Curriculum (KTSP, Kurikulum Tingkat Satuan Pendidikan). Based on the results of expert judgment that has been published into the public test of 2013 Curriculum, it is found that the previous curriculum, namely the Educational Unit Level Curriculum, has suffered from several problems. One of the problems is that the existing competencies have not been able to describe the domain of attitude, skills, and knowledge holistically. 
Jurnal Prima Edukasia, 5 (2), July 2017 - 173

Putri Zudhah Ferryka

2013 Curriculum does not change the element of Educational Unit Level Curriculum in overall. The elements that have been changed, then, are namely the graduate's competence standard, the process standard, the content standard, and the assessment standard. The change on the graduate's competence standard can be found in the improvement of the balance between the soft skills and the hard skills, which include the aspects of attitude, skill, and knowledge competence. The learning process in each theme of elementary schools is conducted using the scientific approach. Then, the change on the content standard can be found in the position of the competencies; in the new curriculum, the subjects are developed from the competencies through the integrative thematic learning process. The assessment standard in 2013 Curriculum itself now applies the authentic assessment, namely measuring all of the attitude, the skill, and the knowledge competencies based on the process and the results.

The results that have been revised in 2013 Curriculum can be found in the Ministry of Education and Culture Regulation Number 67 Year 2013 that emphasizes on the improvement on the paradigm change within the learning process. The learning process that used to be centered on the teacher now is centered on the students along with the use of interactive learning process among teacher-student-societyenvironment. Students should have options toward that they will learn in order to attain similar competencies. By turning the passive learning into the active learning, students can learn from anyone in anywhere using the groupbased or the team-based learning. The other improvement lies in the pattern of mass-based learning process that becomes the user's needs; such improvement is pursued by reinforcing the development of special potentials that each student possesses.

2013 Curriculum presents new matters for the learning process in the classroom, which teachers should understand in order not to be confused in implementing the new curriculum. These new matters are as follows: (1) integrative thematic learning; (2) scientific approach; and (3) authentic assessment. The presentation of 2013 Curriculum with the integrative-thematic learning model is intended to associate several subjects and learning materials so that the learning process may provide meaningful learning experience for students.
The integrative-thematic learning is relevant for accommodating the qualitative differences in the learning environment. This learning is able to inspire students in their thinking skills. The learning process that makes use of scientific approach is intended to provide understanding to the students in introducing and understanding multiple learning materials. Information may come from anywhere in anytime and information does not depend on the one-way communication that teachers have been conducting; as a result, the learning condition is in accordance with the expectation. Assessing the students by means of authentic assessment emphasizes on what aspects that should be assessed, both in the process and in the results, using multiple assessment instruments. This assessment technique embraces three domains of learning competencies that have been integrated namely attitude, skill, and knowledge. Such assessment is able to describe the improvement on the students' learning results in observing, raising questions, gathering information, associating information, and communicating information. However, the teachers' mindset from the old learning pattern to the new learning pattern is still difficult to change. Similarly, the old learning habit which tends to prefer to lecture than investigation is still difficult to change. In order to deal with such situations, the government have been pursuing multiple efforts in order to get gain a successful implementation of 2013 Curriculum training and socialization throughout all regions in Indonesia.

The implementation Curriculum 2013 should be supported by sufficient facilities and one of them is the learning set. In relation to this statement, learning media are one of the learning sets that have an important role in teachinglearning activities. The use of learning media should be given attention by teachers in every learning activity. However, the design of learning media is often abandoned under various reasons such as: the limited time for preparing the teaching activities, the difficulties in looking for the appropriate media, the unavailable learning media, and more. Such situation will not happen if each teacher has already attained knowledge and skills regarding learning media. Such situation can also be a problem that may cause the delay to the optimum implementation of 2013 Curriculum; as a result, the new curriculum has not been able to implement throughout Indonesia. Only several schools have implemented the new curriculum. Improvement 
Jurnal Prima Edukasia, 5 (2), July 2017 - 174

Putri Zudhah Ferryka

should be improved in order that the new curriculum might fit into the overall educational conditions in Indonesia. This effort is in accordance with the statement by the Ministry of Educational and Culture (Kementerian Pendidikan dan Kebudayaan, 2014) which mentions that "elementary and high education unit that has implemented 2013 Curriculum for 3 (three) semesters should keep implementing the 2013 Curriculum."

In addition to media, another learning set that becomes the attention in the implementation of 2013 is the textbook. The implementation of integrative thematic learning in 2013 Curriculum is manifested in the form of interrelated textbooks for both teachers and students. Textbook becomes another factor that supports the success of 2013 Curriculum implementation.

The existing textbook should be able to present meaningful learning materials for students as the learning subject and for teachers as guideline. The teacher book contains manual on the use of student book and on the implementation of scientific approach-based learning activities in classroom which entails learning strategies, learning methods, learning techniques, and authentic assessment. On the other hand, the student book elaborates the minimum effort that student should perform in order to achieve the expected competencies.

The textbooks that have been implemented since the learning process on 2014/2015 Academic Year are those for Grade I, II, IV, and IV; these textbooks have been published by the Ministry of Education and Culture. The textbooks for Grade I and Grade IV have been revised because they were monitored and were evaluated by the Ministry of Education and Culture in 2013. These books have been validated through an analysis test by the National Board on Educational Standard (BNSP, Badan Nasional Standar Pendidikan). However, the results of analysis test by the Board were not publicly reported; as a result, public do not know the results. Therefore, the content feasibility of 2013 Curriculum textbooks have not been measured in terms of integrative thematic content, scientific approach-based learning process, and authentic assessment.

Then, the textbooks for Grade II and V are newly implemented in 2014. Both the teacher book and the student book for these grades have passed the analysis test by the Board; however, the government still gives an opportunity for the public to analyze both books. This statement is confirmed by the foreword part of 2013 Curriculum textbooks for Grade II and $\mathrm{V}$. In this part, it is written that the government still gathers suggestions, criticisms, improvement, and revisions for the next edition in order to improve both the teacher book and the student book. Therefore, these textbooks should be reviewed further in order to attain information regarding the conformity between the content and the curriculum. The content conformity that is intended refers to the integrative thematic content, the scientific approach-based learning, and the authentic assessment.

Based on the above explanation, content analysis should be conducted to the textbooks that have been published by the Ministry of Education and Culture. This study, then, will conduct a content analysis toward the textbook for Grade II students under the theme Harmonious Life. This theme serves as the preliminary learning material in Grade II, which strives to internalize the process of character development in the learning process. In internalizing this character, teachers have a very important role (Apriani \& Wangid, 2015, p. 16). The harmony among religious people refers to the first sila in Pancasila; this sila serves as the basis of practicing the other sila. Indonesia consists of various tribes, religions, races, and culture; as a result, harmony will be the first basis that should be introduced to the children. Differences should not be disputed but, instead, differences should be turned into the beauty of the life. Therefore, the students should be introduced to this concept as they enter Grade II. In the theme Harmonious Life, the students are provided multiple examples of harmonious life in the daily life. This is in accordance with the Piaget's concept that elementary school students belong to the concrete operational stage, a stage that is characterized by the fact that children can perform logical reasoning by using specific/concrete examples.

Recalling the importance of this material, there should be an analysis toward the textbooks of 2013 Curriculum. This study then strives to analyze the textbook using the content analysis and the content analysis will be limited to: (1) the integrative thematic contents; (2) the scientific approach contents; and (3) the authentic assessment contents. The three contents are selected because they become the main element in the implementation of 2013 
Jurnal Prima Edukasia, 5 (2), July 2017 - 175

Putri Zudhah Ferryka

Curriculum. In conducting this content analysis, the researcher formulates the following objective: to describe the integrative thematic contents, the scientific approach contents, and the authentic assessment contents in the 2013 Curriculum textbook for Grade II students under Theme I Harmonious Life.

Curriculum is one of the elements that contribute to the manifestation of well-qualified development on the students' potentials. Kelly (2009, p. 7) defined curriculum as follows: "Curriculum defined in terms of what teaching and instructions is to be offered and sometimes also what its purpose, its objectives." This statement implies that curriculum has certain objectives to achieve when it is implemented into the learning process. Similarly, Kridel (2010, p. 227) stated that curriculum purposes typically include the goals, aims and objectives of an educational program." This statement implied that the purpose of a curriculum consists of objective educational targets, objectives, and programs. The target of 2013 Curriculum is written in the Graduate Standards of Competencies, the purpose of 2013 Curriculum is written in the Standard of Content, and the educational program is written in the Standard of Process and the Standard of Assessment. The Standard of Content is a derivation from the Graduate Competence Standard, which consists of Core Competence and Basic Competence.

Curriculum as a learning program planner can be found in the Law of Republic Indonesia Number 20 Year 2003 Verse 1 regarding the National Education System. Curriculum serves as a set of plan and arrangement regarding the purpose, the content, the learning materials and the manners in implementing teaching-learning activities in order to achieve certain educational objectives. Curriculum includes the content planning an arrangement, which consists of the efforts to achieve the related objectives. In other words, curriculum is a master plan for achieving the educational objectives.

Ornstein \& Hunkins (2009, pp. 100-110) explained that there are 5 fundamental definitions of curriculum namely: (1) curriculum as a plan to achieve target; (2) curriculum as an elaboration on the students' experience; (3) curriculum as a system; (4) curriculum as a scope of study; and (5) curriculum as a subject. Similarly, Phillion (2008, p.8) defined that curriculum is defined as an official statement of what students are expected to known and able to do. This is to imply that curriculum as an official guideline demands the students to understand and to implement the curriculum contents. Based on this definition, the researcher may conclude that curriculum is a set of learning plans that have wide dimension. This dimension includes planning, objective, material, objectiveachievement manner, evaluation, and implementation in the learning process according to the objectives that have been set. The conclusions that might be drawn from this definition, then, is that curriculum as a set of written learning programs that includes objective, material, evaluation, and implementation in the learning activities that have been formulated by the laws in order to ease the learning process.

2013 Curriculum is presented using integrative thematic learning. In more details, Zubaidah (2015, p. 49) stated that an effective environment of elementary school classrooms certainly has integrative-thematic sense. This statement implies that learning environment should be effective in order to achieve an integrative-thematic sense. This type of learning process makes use of themes for associating several subjects to the learning materials so that the learning process might provide meaningful learning experience for the students. The reason is that such meaningful learning process provides direct experiences completely and holistically with regards to the matters that will be useful in their daily life.

The concept of integrative thematic learning has been proposed by several experts. According to Fogarty (2009, p. 95), thematic approach offers the students a realistic thinking in which they may pursue the learning process using multiple contexts and sources according to their demands and their contexts realistically. Fogarty (2009, p. 95) supported the statement made by Frederiks, which mentions that the use of integrated model is internalized within disciplines of science as an inductive process in differentiating skills, attitudes, and knowledge. The more we share, the more we will find similarities. Based on the statement, the researcher may conclude that through the use of thematic learning students may learn several subjects in the same time so that they will have more meaningful experiences. This conclusion is relevant to that of Setyawan \& Mustadi (2015, p. 109), which states that thematic learning in elementary schools is an implementation of thematic learning process that integrates several intra-subject and inter-subject aspects. The 
integrative thematic learning makes use of theme as the connector of learning activities that integrate several subjects. The learning activities in one meeting provide a meaningful experience for the students in understanding the concepts. Students may learn through direct experiences by establishing association to other concepts that they have learned. Zubaidah (2015, p. 50) stated that direct experiences that have been attained from the use of concrete objects are the characteristics of learning styles in elementary schools. This statement implies that the learning process in elementary schools is conducted using the concrete objects.

2013 Curriculum asserts the implementation of scientific approach in the learning process (Kementerian Pendidikan dan Kebudayaan, 2014, p. 18). The scientific approach is believed to be the stepping stone for the growth and the development of the students' attitudes, skills, and knowledge. The scientific approach is conducted by inviting the students to take any participation in the learning process (Zubaiah, 2015, p.51). Prunckum (2010, p.44) explained the steps in the scientific approach as follows: Scientific methods of inquiry are founded on the steps of the intelligence cycleproblem formulation, data collection, data collation, analysis (including hypothesis testing), and dissemination.

The activities that are found in the scientific approach, unfortunately, should not always be conducted in chronological sequence; instead, they can also be conducted in random sequence. However, all of the learning activities should be maintained. A learning process should touch three domains namely attitudes, knowledge, and skills. The activities of scientific approach include observing, raising questions, experimenting, reasoning, and communicating (Majid, 2014, p. 211).

The focus of emphasis in 2013 Curriculum is the authentic assessment. Authentic assessment has a strong relevance to the scientific approach in the learning process of 2013 Curriculum. The reason is that this assessment is able to describe the improvement on the students' learning results in their activities of scientific approach. The authentic assessment is well known as the actual assessment that has been administered to the students. According to Mardapi (2012, p. 166), the authentic assessment is different than the traditional assessment in several aspects. The students tend to choose the available response in the practice of traditional assessment, while they have to perform a task within the practice of authentic assessment. Brookhart (2011, pp.246247) stated that authentic assessment usually means presenting student with tasks that are directly meaningful to their education. Then, the assessment that has been intended in this textbook analysis is already in accordance with the one that has been intended in 2013 Curriculum, namely the assessment that evaluates the overall aspect of attitudes, knowledge, and skills during and after the learning process.

The presence of textbooks and materials are heavily demanded and both of them should be available in order to achieve the learning objectives. Saleem \& Thomas (2011, p. 18) justified that textbooks are strong set of equipment in the teaching-learning process. Textbooks are references for teachers in delivering the materials to their students. The position of textbooks is very important both for the teachers and the students. The benefits of textbooks are not only perceived by the students but also by the teachers. This statement is in accordance with that of Sari \& Syamsi (2015, p. 78) who stated that teacher book is used as the manual for the student book and the conduct of teaching-learning process in the classroom. In other words, the teacher book serves as the manual of student book in the learning process.

Textbooks are designed by experts in their respective domain both individually and cooperatively so that the textbooks might be considered well qualified, meeting the standards of science, and in accordance with the governing curriculum that has been implemented in the classroom in order to achieve the learning objectives. Teachers should select textbooks appropriately in order that the textbooks will be significant in supporting the learning process by paying attention to several criteria of selection.

The role of education is also inseparable from that of curriculum as a means to achieve the learning objectives; as a result, textbooks also play a role in the curriculum as a means to achieve the learning objectives. This statement is in line with a statement by Reynold in Ho \& Hsu (2011, p. 93): “Textbooks are the key to curriculum development and implementation through dissemination to teachers and students..." This statement implies that textbooks are a means of curriculum implementation. Kraja (2012, p. 237) added that textbooks provide a dominant role in the 
curriculum; therefore, textbook authors are responsible for designing textbooks in supporting students and in responding to the modern development. In relation to this, text evaluation has an important role because it serves as the main means of curriculum evaluation.

Textbooks and curriculum have close association. Textbook design should be in accordance with the curriculum. Therefore, textbooks should be analyzed in terms of content in relation to its fitness into 2013 Curriculum. The textbooks of 2013 Curriculum consist of teacher book and student book and the student book should contain the design of scientific approach and authentic assessment. Then, a textbook will be considered as being fit into the scientific approach if the textbook contains the activities of observing, raising questions, gathering information/experimenting, and communicating (Kementerian Pendidikan dan Kebudayaan, 2014, p. 53). The fitness between the textbook and the curriculum should exist; therefore, this study shall focus more on the fitness between the teacher book, the student book, and the governing curriculum.

\section{Method}

The study made use of qualitative approach using content analysis. The study then was conducted from December 2014 to June 2015. The data sources consisted of the research subjects and the research object. The object of this study was the integrative thematic textbooks of 2013 Curriculum for Grade II students under Theme 1 Harmonious Life that had been designed and had been issued by Kemendikbud (The Ministry of Education and Culture). The textbooks consisted of the teacher book and the student book. Then, the researcher would study the integrative thematic content, the scientific approach, and the authentic assessment contained in the textbook.

The data gathering techniques in this study were the close reading and note toward the integrative thematic content, the scientific approach, and the authentic assessment within both the teacher book and the student book. The main instrument that would be applied in the study was human instrument, namely the researcher herself. The researcher made use of a document analysis sheet that would ease her in categorizing the data. This analysis sheet was designed based on theoretical foundations regarding the integrative thematic learning, the scientific approach, and the authentic assessment.

Next, the data validity was based on the validity and the reliability. The validity that had been applied in this study was the semantic validity and the semantic validity was pursued by viewing the data fitness and significant according to the concept. For validating the data and the instrument, the researcher performed expert judgment. The experts whom the researcher had referred to in consulting the document of analysis sheet were two and both of them came from the domain of language. Then, the reliability test that the researcher applied was the stability and the inter-rater test. The stability test was conducted by scrutinizing the data over and over in order to gain the consistent understanding. On the other hand, the inter-rater test was conducted by discussing and confirming the findings to the experts and the colleagues. The colleagues whom the researcher had referred to were people who had knowledge and relation to the content analysis. The experts whom the researchers had consulted to in scrutinizing the findings in this study were an expert in linguistics. Then, the colleague was an undergraduate student who had been conducting a content analysis.

Last but not least, the data analysis technique that the researcher applied was the content analysis scheme by Krippendorff (2004, p. 83). This scheme consisted of unitizing, sampling, recording, reducing, inferring, and narrating stage.

\section{Results and Discussions}

Results

The integrative thematic content, the scientific approach, and the authentic assessment in the textbooks for Grade II students under the Theme 1 Harmonious Life in overall had been integrated to each learning process. In relation to the integrative thematic content, there were three aspects which indicators could be found in each learning process. The aspect of integration consisted of three indicators. The aspects of integration into the learning indicators included several learning materials that had been elaborated into the textbooks. Each learning process contained several subjects that had been integrated. The number of the subjects might be found from the basic competencies and the indicators that had been formulated in the teacher book. The 
Jurnal Prima Edukasia, 5 (2), July 2017 - 178

Putri Zudhah Ferryka

number of subjects in each learning process was not equal; the number of these subjects was determined according to the map of basic competencies that had been applied. All of these subjects were holistic, combining all of the basic competencies (spiritual attitude, social attitude, knowledge, and skills) in order to establish association with the theme. The concept of knowledge was associated to the attitude competencies and the skill competencies, which referred to the basic competencies that the students should develop. Every learning process developed the competencies of spiritual attitude, social attitude, knowledge, and skills within the subjects. The integration was not only pursued in the inter-subject level but also in the intercompetencies level in each subject. Inter-subject separation was not apparent or was vague as having been apparent in the student book; the transition from one subject to another was always preceded by a text that had been related to the previous material. Meaningful learning as one of the aspects in the integrative thematic learning process had been applied in this study. Based on the results of the study, the researcher found that all of the indicators in the aspect of meaningful learning within the integrative thematic content had been applied in each learning process. The learning process centered on the students, which had been a learning process that directed the students to actively build their own knowledge.

The scientific approach content in the textbooks consisted of five aspects. Not all of the indicators in the aspects of scientific approach had been met. The five aspects of this scientific approach were observing, raising questions, experimenting, reasoning, and communicating. Every aspect had different number of indicators and not all of these indicators had been met.

Then, the aspects of the authentic assessment content included the attitude assessment, the knowledge assessment, and the skills assessment. The results of this study on the assessment authentic content showed that not all of the indicators in the three aspects above had been met in each learning process. However, fitness was apparent both in the assessment rubric of the teacher book and the assessment activities of the student book. Unfortunately, the attitude assessment that had been found in the textbook under analysis only contained the social attitude assessment and had not contained the spiritual attitude assessment.
The skills assessment had been integrated in the achievement of the Basic Competency 4 (KI 4, Kompetensi Inti 4). All of the subjects had the skill aspects as the continuation of the knowledge aspects (Basic Competence 3 or KI 3, Kompetensi Inti 3) that the students had mastered.

\section{Discussions}

Based on the results of the study, the researcher has found that the integrative thematic content has been integrated into the learning process. The integrative thematic content consists of three aspects namely integration, meaningful learning, and studentcentered learning. Every aspect in this content consists of three indicators. For example, the aspects of integration consist of three indicators. The first indicator is learning process includes several disciplines that have been integrated into one theme. This indicator has been in accordance with the opinion by Majid (2014, p. 86), which proposed that a thematic learning has been a learning strategy that involves several subjects in order to provide meaningful learning experiences for the students. The meaningful experiences are expected to help the students in understanding the concepts that they learn through their direct and factual experiences. These direct and factual experiences then will be integrated into several inter-subject basic competencies using the related theme. In the indicator map that can be found within the teacher book, there are several mistakes due to the author's unpunctuality; for instance, the author had a mistake in writing the basic competencies that should be in accordance with Permendikbud Nomor 67 Tahun 2013. In the same time, there has also been a mismatch between the materials and the basic competencies that have been written in the book.

Another finding in this aspect is that every learning process contains several disciplines that have been integrated under one theme such as Mathematics, Bahasa Indonesia, PPKn, SBDP, and PJOK. This finding is already in accordance with the opinion by Rusman (2011, pp. 251-252) in relation one of elementary school students' characteristics namely being integrative in viewing the matter under study as the needs and the unity. In addition, Mathematics is always associated to the previous contents. Such association is in accordance with the opinion by Berk (2013, p. 416) who stated that in order to decrease errors 
Jurnal Prima Edukasia, 5 (2), July 2017 - 179

Putri Zudhah Ferryka

in Mathematics students should be provided with wide opportunities to solve problems, to understand the reasons behind the use of certain strategies, and to evaluate the problem-solving techniques that have been applied in the previous activities.

The second indicator regarding the holistic learning incorporates the basic competencies from several subjects in order that these subjects will have association to the theme and such association is a form of integrative thematic learning model implementation by Fogarty (2009, p. 95) namely the connected model. Connected model is the learning model that displays association among topics, concepts, and skills. This thematic model incorporates basic competencies from several subjects which have similarities. Through such learning process, students might develop their attitudes, knowledge, and skills. The learning process seems to be integrated in several subjects that elaborate several basic competencies such as Bahasa Indonesia to KD 3. 3, PPKn to KD 3.3, Mathematics to KD 3.1, and SBDP to KD 3.2.

The third indicator of inter-subject separation is quite clear. As a result, the students learn the subjects holistically. The students' overall understanding is necessary in order to encourage their curiosity in studying many things. This situation is apparent in the student book; every transition in the learning materials is always preceded by texts that will be related to the previous learning materials. This finding is in accordance with the opinion by Andeyemi (2010, p.11) which states that integrative thematic learning does not separate subjects from one to another. Therefore, the subjects should be related from one to another in terms of fundamental issues.

The aspects of meaningful learning consist of three indicators. The first indicator is directing the students to understand the learning concepts holistically and realistically. The learning process that has been conducted contains the concepts in the real life and provides the examples that are close to the students' individual life. Page 5 of the student book provides an example of asking for apology with courtesy, comparing the number of books in each shelf, and writing activities in the diary. Then, the second indicator is directing the students to learn something that will be useful in their daily life. The examples that have been provided in the learning process are also relevant to the students' real life. This finding is in accordance with the existing theory; according to Rusman (2011, p. 258), thematic learning has several characteristics namely concentrating on the students' life, providing direct experiences, having unclear subject separation, providing concepts from various subjects, and having flexibility. Last but not least, the third indicator is providing direct experiences to the students. The learning activities that direct the students to be directly involved are apparent in the use of active sentence within the student book, for example: "Let's Sing, Let's Do Some Exercise, Let's Observe, and Let's Write" ("Ayo Bernyanyi, Ayo Berlatih, Ayo Mengamati, and Ayo Menulis'). The role of teachers as a facilitator is manifested in such learning process. The manifestation can be seen from the instruction of learning activities that might be performed based on the teacher book. The teachers only explain the general part and the students will do the rest of the learning activities.

The presence of direct experiences in the student book can be seen in the process of finding information that is related to their study. The experiences that have been provided to the students are expected to bring closer the knowledge that they should attain. This statement is in line with the opinion by Hosnan \& Sikumbang (2014, p. 366), who stated that thematic learning presents real world application-based experiences. The direct experiences should be attained in order that the students become more enthusiastic in attending to the learning process. The students' curiosity can be directly applied within the learning process through the attainment of direct experiences. The students can learn directly from their environment in order to attain the knowledge that they should master. According to Slavin \& Samosir (2009, p. 100), elementary school students have not been able to perform abstract thinking. Therefore, concrete examples are necessary in order to help the students in understanding the concepts that they are studying.

The aspects of student-centered learning consist of three indicators. The first indicator invites the students to be actively involved in the learning process (as a learning subject) and the teachers will be a facilitator in the learning process. The second indicator makes use of the "play and have fun" learning principle. The third indicator invites the students to establish social interaction with their social environment in 
order to establish their knowledge. The findings that have been gathered from the student book are related to the activities of observing, raising questions, gathering information, associating, and communicating; all of these activities are part of scientific approach. The directions for performing this learning process can be found in the teacher book.

The second indicators, "play and have fun" learning principle, is always applied in each learning process. The application is apparent in the games or the songs and both of them can be integrated in order to create something fun. Learning by playing games will encourage the students to be enthusiastic within the learning process. The principle of "play and have fun" is necessary in the learning process especially among the lower class (Grade 1 to Grade 3) students. This is in accordance with the characteristics of Grade 2 students who are still fond of playing around, as having been proposed by Berk $(2013$, p. 399) that elementary school students experience rough and soft motor development. Playing activities, in the same time, are necessary for developing the students' motor skills especially the rough ones. The students will think that they have merely been playing around instead of learning, whereas actually they are establishing the knowledge that is inserted into their playing activities. Through the same learning activities, social and spiritual values can also be internalized in their daily life.

The third indicator in the learning process invites the students to establish social interaction with their environment in order to establish their knowledge. Establishing interaction with environment is part of the process for attaining knowledge. From the textbook, the researcher has found that interaction is related to the natural environment and the social environment. This finding is in accordance with the students' social development that has been proposed by Slavin \& Samosir (2009, p. 101), namely that the stage of students' social development consists of developing independent action, developing group cooperation, and developing social performance. Independent action is related to exploration toward the surrounding environment. Then, group cooperation and social performance are related to the discussion process and information gathering from resources.

The integrative thematic content has been widely distributed into the learning process; as a consequence, the learning process that has been presented in this textbook is already in accordance with the characteristics of the integrative thematic content. This findings has also been in accordance with the concept of integrative thematic learning that has been proposed by Rothein (1995, p.5); this concept might be defined as a thematic learning process that incorporates subjects structurally, sequentially, and reasonably well. The thematic approach directs the students to think realistically so that they may use multiple learning resources up to their needs.

The scientific approach content is always applied in each learning process with various learning materials according to the subthemes. There are five aspects that have been referred to in the scientific approach stage, namely: (1) observing; (2) raising questions; experimenting; (4) reasoning; and (5) communicating. These stages become the main scenario of the learning process within the textbook. The implementation of this learning process does not attend to the sequence; instead, the learning process is adjusted to the existing learning materials.

The aspect sequence in Theme 1, according to the frequency of application, in the learning process is as follows: (1) observing; (2) reasoning; (3) experimenting; communicating; (5) raising questions. The aspect of observing is put in the first order. This aspect is very useful for meeting the students' curiosity; as a result, the learning process will have high sense of meaningfulness. Based on the data description that has previously been discussed, the indicator that has been frequently applied is viewing the object/the material that will be studied. This finding is accordance with the statement by Patton in Hosnan \& Sikumbang (2014, p. 41) regarding the objective of observing, namely to attain better understanding about the material under scrutiny. This activity is expected to stimulate the students in developing the competencies of thoroughness, the exercise of persistence, and the search for information according to the materials that they are learning.

The aspect of reasoning is put in the second order. This aspect is performed by processing the information that has been gathered, analyzing the data using categorization, relating or associating the related information/the phenomena in order to find a pattern, and drawing conclusions. These activities are in accordance with The Minister of 
Jurnal Prima Edukasia, 5 (2), July 2017 - 181

Putri Zudhah Ferryka

National Education Regulation Number 103 Year 2014 (Menteri Pendidikan dan Kebudayaan Republik Indonesia, 2014). The indicator that has been frequently applied is processing the information that has been gathered. The competencies that have been expected to develop from the reasoning activity are honesty, thoroughness, discipline, compliance, hard work, procedure-implementing capacity and also inductive- and deductivethinking capacity in drawing conclusions.

The aspect of experimenting is put in the third order. In general, this aspect encourages the students to be able to develop their selfconfidence and critical thinking and directs the students to be directly involved in the process of attaining their knowledge. Next, the aspect of communicating is put in the fourth order. In the scientific approach, teachers are expected to provide opportunities for the students in communicating what they have learned. The communicating activity can be clarified by the teachers in order that the students understand whether their answers have been correct or not; if their answers are not correct yet, then the students should revise their answers. This activity can be directed toward the activities of confirmation as having been written in the process standard. Then, the competencies that have been expected to develop from this aspect are honesty, thoroughness, tolerance, systematic thinking skills, brief and concise opinion sharing, and good language development. The communicating activity in this learning process is performed by composing reports in the form of charts, diagrams, or graphics, by composing written reports, or by drawing conclusions orally. This activity is already in accordance with the Minister of National Education Regulation Number 103 Year 2014 (Menteri Pendidikan dan Kebudayaan Republik Indonesia, 2014). Based on the data description that has been previously discussed, the indicator that has frequently been used in this activity is composing the oral and the written report.

The aspect of raising questions is put in the fifth or the last order because it has the lowest frequency of application. The indicator of performing discussion regarding the additional information that the students would like to understand as part of optimal clarification has rarely been applied in the learning process. Raising questions activity can develop the students' creativity, curiosity, and question formulating capacity in order to shape the critical thinking that will be necessary for their intelligent life and life-long learning. Effective teachers are the ones who have been able to inspire their students to improve and to develop the domain of their attitudes, skills, and knowledge; the improvement of this domain can be developed by the raising questions activity. Teachers will guide students to learn appropriately when the students ask them. Students may ask the information that they have not understood. Teachers then will motivate the students to be a good learner and listener. Based on this explanation, it can be concluded that the learning process in Theme 1 Harmonious Life has already made use of the scientific approach themes. The learning principles that have been applied has already been in accordance with the opinion by Hosnan \& Sikumbang (2014, p. 37) regarding the learning principles with the use of scientific approach that centers on the students.

The authentic assessment that has been analyzed in this textbook consists of three aspects namely: (1) assessment of attitude that consists of spiritual attitude and social attitude; (2) assessment of knowledge; and (3) assessment of skills. The three aspects have various indicators. From the results of textbook analysis, the researcher has found all of the authentic assessment contents. The sequence of assessment that has frequently been applied based on the above data description is the assessment of attitude, the assessment of skills, and the assessment of knowledge.

The assessment of attitude is an assessment that has been performed in order to observe the students' attitude during the learning process. Then, the assessment of attitude consists of four indicators. The first indicator is the observation that teachers perform during the learning process. The second indicator is the self-assessment that the students perform alone in relation to their competence achievement. The third indicator is the peer assessment using an assessment sheet that aims to measure the level of their competence achievement. The fourth indicator is the journal that teachers use in taking notes on the students' attitude in relation to their strengths and weaknesses. From the four indicators in this assessment of attitude, it seems that two indicators not been applied in Theme 1 Harmonious Life namely the third and the fourth indicator. The reason is that the students assessed their peers at the end of the learning process and that the teachers made use of their journal without referring to special guideline; 
Jurnal Prima Edukasia, 5 (2), July 2017 - 182

Putri Zudhah Ferryka

the teachers only made use of their personal notes. The assessment of attitude is very important to conduct because attitude determines the students' behaviors, as having been proposed by Johnson \& Johnson (2002, p.168): attitudes are important of behavior.

The indicators that have been found in the assessment of attitude are the first and the second indicator. Then, the indicator that has not been applied in this theme is the peer assessment, which urges the students to assess one to another using peer assessment sheet in order to measure the level of their competence achievement. The first indicator is observation assessment; this indicator has frequently been found than the second one. The fitness between the assessment rubric in the teacher book and the assessment activities in the student book has been considered good. However, an improvement should be made here since the researcher only found the assessment of social attitude such as self confidence, thoroughness and courtesy during the textbook analysis. An example of the spiritual assessment has not been found in the textbook.

The observation assessment has already in accordance with the first basic competence, namely elaborating attitudes that are related to the undergoing learning process. The observation results have been noted as written evidence according to the guidelines that have been designed. The rubric of observation assessment that has been presented in the teacher book is limited on the social aspect, unfortunately. As having been explained in the previous paragraph, the social attitudes that the researcher has found in the assessment rubric on Theme 1 Harmonious Life include self confidence, thoroughness, and courtesy. The activities of attitude observation anyway have already been in accordance with the Core Competence and the Basic Competence. However, the rubric of spiritual attitude assessment has been absent.

Self-assessment should be conducted by the students alone. The students should understand the use of self-assessment in order to perform this assessment according to the attitudes that they have displayed, as having been stated by Meinbach, Rothlein, \& Fredericks (2000, p. 5): when students take participation in evaluating their own progress, they will start developing a sense of responsibility. Self-assessment will be able to develop the students' sense of responsibility if the students perform it well. Self-assessment demands the students' honest in assessing themselves. The students will complete a checklist according to their attitudes during the learning process. The implementation of selfassessment will develop the sense of honesty in assessing their performance. Therefore, the students should be trained in assessing themselves according to the attitudes that they have been displaying during the learning process. In order to eliminate the subjectivity within their self-assessment, the students should be provided with clear and objective criteria. According to Clarke (2005), According to Clarke (2005, p. 120), if the students are not limited in performing their self-assessment they will perform the errors such as over assessing themselves. The clear and objective criteria are necessary in order to avoid subjectivity.

In 2013 Curriculum, the attitude competencies, both the spiritual attitude (Core Competence 1) and the social attitude (Core Competence 2), are not elaborated in the learning process. These competencies should be implemented through habituation and role model in actual actions that the students display in their life through the accompanying impacts from the learning process. In other words, teachers who teach these attitudes actually teach the knowledge of attitudes such as self-confidence, thoroughness, and courtesy. This assessment can be performed altogether with the teachinglearning process both directly and indirectly.

The aspect of knowledge assessment consists of two indicators. The first indicator is related to written test, while the second indicator is related to oral test, discussion activities, question and answer session, and conversation. This assessment is integrated into the achievement of Core Competence 3 with regards to knowledge. The knowledge competence reflects the scientific concepts that the students should master through their learning process. The indicators that have frequently appeared in this study are the multiple objective test and the essay test complete with the answer keys and the scoring techniques. The other indicators rarely appear both in the teacher book and the student book. The written assessment in the student book has been performed by administering the short answer test items complete with the answer keys and the scoring guidelines of each test item. However, there are several errors with regards to the answer keys. The written assessment, by the way, has been administered 
and has been supplied with the answer keys. The objective is training the students' skills in solving the problems that they encounter according to the learning materials that they have learned; the answer to the test items will be limited to the answer keys that have been selected. According to Wilson (2009, p.247), short answers demand students to master vocabulary, phrases, numbers, or symbols in order to respond the test items.

The form of written assessment is applied in order to measure the students' competence achievement in the form of knowledge or the cognitive aspect. Then, the form of oral assessment is also applied in order to test the students both individually and communally in relation to the same aspect. The oral test demands the students to provide oral answer by having question and answer session directly with their teacher.

The assessment of skills is frequently found in the textbook. The aspect on the assessment of skills consists of three indicators. The first indicator is performing observation activities using performance assessment. The second indicator is performing portfolio assessment by asking the students to submit their artworks in a certain period of time. Last but not the least the third indicator is performing project assessment. From the three indicators, the first indicator is the only indicator that has been met in each sub-theme. The second and the third indicator are not found in Theme 1 Harmonious Life at all.

The assessment of skills competence is the one that should be conducted by observing all student activities in performing their task. The observation object can be the students' task in completing a process or manufacturing a product as part of their knowledge and skills implementation. The indicator that should be used in the assessment of skills is the first indicator, namely performing activities under the performance appraisal. The observation upon the students' performance is conducted in various contexts in order to determine the level of students' certain achievement.

Performance assessment is also known as performance appraisal. The activities of completing a process or of manufacturing a product are the form of applying the knowledge or the skills that the students have. Therefore, the performance appraisal is often identical to the assessment that measures the application of knowledge and skills that the students have mastered. This assessment is in accordance with the opinion by Brookhart (2011, p.250): performance appraisal should assess the students under certain targets and rubrics that have been set. The rubric of performance appraisal should be consulted as the guideline in assessing the students' learning process. Performance appraisal will assess the learning process that the students have been undergoing. The learning process that the students have been undergoing is accompanied with the real life-related games in which the students' activities will be assessed.

Based on the above explanation and description, the use of the three aspects in this analysis has been in accordance with the opinion by Kunandar $(2013$, p.37) in relation to the description of a balance among attitude, skills, and knowledge in 2013 Curriculum. Authentic assessment pays attention among attitude, skills, and knowledge that has been adjusted to the students' characteristics in each educational degree. The higher the students' educational degree, the wider the mastery of their competence and skills will be. Therefore, in the elementary education degree the internalization of the attitude competence is more asserted.

The content of authentic assessment in overall has been integrated into each learning process. There are three aspects that the researcher has analyzed in relation to the content, namely: (1) the assessment of attitude, which includes the social attitude and the spiritual attitude; (2) the assessment of knowledge; and (3) the assessment of skills. Each of the three aspects has various indicators. The assessment sequence that has been frequently used, based on the above data, is the assessment of skills, the assessment of knowledge, and the assessment of attitude. The content on the assessment of skills that has been elaborated into the textbook belongs to the performance appraisal. Then, the content on the assessment of attitudes that has been elaborated into the textbook belongs to the social attitude assessment; as a result, the spiritual attitude assessment has not been elaborated. However, the assessment content in the textbook has already combined various assessment techniques; as a result, the teachers are assisted in describing the comprehensive students' competence from the aspects of attitudes, skills, and knowledge.

The 2013 Curriculum textbook for Grade 2 Students under Theme 1 Harmonious Life has already applied the assessment technique that is 
appropriate to the requirements of competence achievement that have been designed. The achievement of Core Competence 1 and Core Competence 2 (KI 1 and KI 2) is integrated into the assessment of attitudes. Then, the achievement of Core Competence 3 (KI 3) is integrated into the assessment of knowledge. Next, the achievement of Core Competence 4 (KI 4) is integrated into the assessment of skills. The assessment technique that has been elaborated in the textbook is already integrated into the standards of achievement that has been designed.

\section{Conclusions}

Based on the results of the study and the discussions, the researcher would like to draw the following conclusions. The thematic integrative content in the 2013 Curriculum Textbook for Grade 2 Students under Theme 1 Harmonious Life, consisting of the Teacher Book and the Student Book, in terms of meaningful learning experience and studentcentered learning process has been in accordance with the indicators. Few aspects of fitness, however, have not been in accordance with the indicators due to the authors' errors. Then, the scientific approach content has always been applied in each learning process. The scientific approach sequence in this textbook is arranged from the most frequently used to the most rarely used and the sequence is as follows: (1) observing; (2) reasoning; (3) experimenting; (4) communicating; and (5) raising questions. The aspects of observing that have frequently appeared in the learning process is viewing the objects or the materials that will be studied. Then, the aspect of raising questions that has frequently appeared in the learning process is discussing the information that has not been understood. Next, the aspect of experimenting that has frequently appeared in the learning process is performing activities as the effort to understand the materials; these activities can be singing songs, playing games, and completing test items. Furthermore, the aspect of reasoning that has frequently appeared in the learning process is processing the information that has been gathered based on texts or figures. Last but not the least, the aspect of communicating that has frequently appeared in the learning process is completing written test items.

The authentic assessment contents are integrated in each learning process. The content on the assessment of attitudes that has been elaborated into the textbook in overall is the social attitude assessment and, as a consequence, the spiritual attitude assessment has not been elaborated. The content on the assessment of knowledge that has been elaborated in the textbook is the written test. Last but not the least, the content on the assessment of skills that has been elaborated in the textbook is the performance appraisal. The sequence that has been designed based on the given data is the assessment of skills, the assessment of knowledge, and the assessment of attitude.

\section{References}

Apriani, A.-N., \& Wangid, M. N. (2015). Pengaruh SSP tematik-integratif terhadap karakter disiplin dan tanggung jawab siswa kelas III SD. Jurnal Prima Edukasia, 3(1), 12-25. https://doi.org/10.21831/JPE.V3I1.4061

Berk, L. E. (2013). Development through the lifespan. Boston: Pearson.

Clarke, S. (2005). Formative assessment in action: weaving the elements together. London: Hodder Murray.

Fogarty, R. (2009). How to integrate the curricula. Thousand Oaks: Corwin.

Ho, H., \& Hsu, Y. (2011). Improving the textbook adoption process in Taiwan. International Education Studies, 4(4), 92. https://doi.org/10.5539/ies.v4n4p92

Hosnan, M., \& Sikumbang, R. (2014). Pendekatan saintifik dan kontekstual dalam pembelajaran abad 21: Kunci sukses implementasi kurikulum 2013. Bogor: Ghalia Indonesia.

Kelly, A. V. (2009). The curriculum: Theory and practice. London: SAGE Publications.

Kementerian Pendidikan dan Kebudayaan. (2014). Materi pelatihan implementasi Kurikulum 2013. Jakarta: Badan Pengembangan Sumber Daya Manusia Pendidikan dan Kebudayaan dan Penjaminan Mutu Pendidikan Kementerian Pendidikan dan Kebudayaan.

Kraja, P. (2012). The Improvement of Albanian Language Textbooks in the Primary School. In Book of Proceedings (p. 217).

Kridel, C. A. (2010). Encyclopedia of curriculum studies. Los Angeles, CA: 


\section{Jurnal Prima Edukasia, 5 (2), July 2017 - 185}

Putri Zudhah Ferryka

SAGE Publications.

Krippendorff, K. (2004). Content analysis: An introduction to its methodology. Thousand Oaks.

Majid, A. (2014). Pembelajaran tematik terpadu. Bandung: Remaja Rosda Karya.

Mardapi, D. (2012). Pengukuran penilaian dan evaluasi pendidikan. Yogyakarta: Nuha Medika.

Meinbach, A. M., Rothlein, L., \& Fredericks, A. D. (2000). The complete guide to thematic units: Creating the integrated curriculum. Norwood, MA: Christopher-Gordon Publishers.

Menteri Pendidikan dan Kebudayaan Republik Indonesia. Peraturan menteri pendidikan dan kebudayaan nomor 103, tahun 2014, tentang pembelajaran pada pendidikan dasar dan pendidikan menengah, Pub. L. No. 103, Peraturan Menteri Pendidikan dan Kebudayaan Republik Indonesia (2014).

Ornstein, A. C., \& Hunkins, F. P. (2009). Curriculum: Foundations, principles, and issues. Boston: Pearson.

Presiden Republik Indonesia. Undang-Undang Republik Indonesia nomor 20 tahun 2003 tentang sistem pendidikan nasional, Pub. L. No. 20, 26 (2003). Indonesia. Retrieved from http://sindikker.dikti.go.id/dok/UU/UU20
-2003-Sisdiknas.pdf

Rusman. (2011). Model-model pembelajaran: Mengembangkan profesionalisme guru. Jakarta: Rajawali Pers.

Saleem, M. M., \& Thomas, M. K. (2011). The reporting of the September 11th terrorist attacks in American social studies textbooks: A muslim perspective. The High School Journal, 95(1), 15-33. https://doi.org/10.1353/hsj.2011.0015

Sari, I. P., \& Syamsi, K. (2015). Pengembangan buku pelajaran tematik-integratif berbasis nilai karakter disiplin dan tanggung jawab di sekolah dasar. Jurnal Prima Edukasia, $3(1)$, 73-83. https://doi.org/10.21831/JPE.V3I1.4070

Setyawan, W. W., \& Mustadi, A. (2015). Pengembangan SSP tematik-integratif untuk membangun karakter disiplin dan kreatif siswa kelas I SD. Jurnal Prima Edukasia, $\quad 3(1), \quad$ 108-119. https://doi.org/10.21831/JPE.V3I1.4072

Slavin, R., \& Samosir, M. (2009). Psikologi pendidikan: Teori dan praktik (Edisi Kedelapan) Jilid 2. Jakarta: PT Indeks.

Zubaidah, E. (2015). Pemanfaatan media pembelajaran untuk menciptakan lingkungan kelas SD (Alternatif penciptaan laboratorium SD yang efektif). Jurnal Prima Edukasia, 3(1), 46-60. https://doi.org/10.21831/JPE.V3I1.4064 